\title{
IDENTIFIKASI PEMBELAJARAN SOSIAL DALAM PENGEMBANGAN BATIK DI KOTA PEKALONGAN
}

\author{
Muhammad Indra Hadi Wijaya ${ }^{1)}$, Artiningsih ${ }^{2)}$, Holi Bina Wijaya ${ }^{3)}$, Nofa Martina A. ${ }^{4)}$, Bagus Nuari P.) \\ 1,4,5 Sekolah Vokasi, Universitas Diponegoro \\ ${ }^{2,3}$ Fakultas Teknik, Universitas Diponegoro

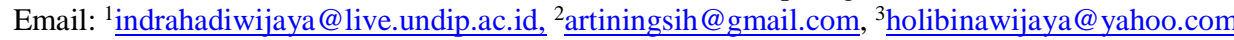 \\ ${ }^{4}$ nofa.ariani@live.undip.ac.id, ${ }^{5}$ bagusnuaripriambudi@live.undip.ac.id
}

\begin{abstract}
Batik as an Indonesian cultural heritage has been recognized by the world in 2009 by UNESCO. This recognition does not fully go hand in hand with the sustainability of batik business and culture in Pekalongan City, especially for business actors in the next generation. This condition is caused by the minimum wage of workers due to the inequality of the subcontracting system in the batik business. This study aims to identify social learning in the batik industry development. The extent to which social learning facilitates the development of batik with regional development. Qualitative methods were carried out for data collection by using in-depth interviews with key business actors in the batik industry chain in the City and Regency of Pekalongan which were selected purposively. The results show that social learning and innovative production processes are still limited with the involvement of the regeneration of young entrepreneurs. The challenges of the batik industry in rural areas depend on how entrepreneurs can enlarge their business networks. This business needs to be more adaptive in utilizing batik not only as an industrial commodity as it is but also processing it creatively as an attraction for Pekalongan City.
\end{abstract}

Keywords: Batik, social learning, sustainability

\section{PENDAHULUAN}

Industri batik di Indonesia umumnya merupakan industri kecil menengah (IKM) yang menjadi mata pencaharian sebagian masyarakat desa dan kota (Wijaya et al., 2020). Karakteristik usaha batik di Indonesia seperti adanya juragan/pemilik usaha dan pekerja/buruh batik. Di dalam sistem ini margin keuntungan yang besar dimiliki oleh pemilik usaha, sedangkan pekerja atau buruh batik masih di bawah standar. Kondisi ini menjadikan regenerasi pelaku usaha batik maupun pekerja/buruh batik masih menjadi tantangan (Nicholas A. Phelps., 2019).

Tenaga kerja yang merupakan pendorong berkembangnya suatu produksi, bila pekerja melakukan aktivitasnya secara efisien maka produksi akan semakin baik, sekarang ini untuk memperoleh tenaga kerja yang terampil dalam industri batik sangat sulit ini semua dikarenakan adanya pandangan pemuda dan pemudi angkatan kerja bahwa pekerjaan membatik (ngecap, batik tulis) adalah pekerjaan untuk orang tua (Tamamudi, 2019). Trend rendahnya minat generasi muda terlibat dalam pengembangan industri batik itulah sekarang ini angkatan kerja untuk industri batik semakin menua dan sulit dicari penggantinya. Di satu sisi hal ini disebabkan oleh minimnya upah pekerja akibat ketidaksetaraan sistem subkontrak dalam pertalian usaha batik.

Di sisi lain perkembangan usaha batik tidak lepas dari pelestarian batik sebagai warisan budaya melalui pembelajaran sosial merupakan tanggung jawab dari semua pemangku kepentingan, mulai dari pelaku usaha, masyarakat dan generasi muda, tetapi dari beberapa kajian masih kepada bagaimana pembelajaran sosial melalui pelatihan dan peningkatan kapasitas bisnis pelaku usaha (Handayani, 2016; Jannah et al., 2020; Kusuma, 2015). Sedangkan untuk pengembangan batik dengan pemanfaatan TIK di Pekalongan masih sebatas kepada pemanfaatan E-Commerce untuk pengembangan bisnis (Maulana et al., 2016; Sulistyorini et al., 2017; Taryadi et al., 2015). Penelitian ini dilakukan untuk mengidentifikasi peluang pengembangan batik 
melalui pembelajaran sosial di Kota Pekalongan untuk keberlanjutan pelaku usaha batik.

Batik sebagai salah satu komoditas dari Indonesia yang memiliki nilai seni dan nilai ekonomi ditunjukkan dengan batik di Indonesia tersebar di beberapa daerah di pulau Jawa yang kemudian menjadi nama dari jenis-jenis batik tersebut seperti Batik Pekalongan, Batik Surakarta, Batik Yogya, Batik Lasem, Batik Cirebon, dan Batik Sragen. Batik dari setiap daerah tersebut memiliki ciri motif yang spesifik (Nurainun, 2008). Batik sebagai kekayaan budaya ini mendorong UNESCO menilai teknik, simbolisme, dan budaya terkait batik yang dianggap melekat dengan kebudayaan Indonesia. UNESCO memasukkan Batik Indonesia ke dalam Representative List pada tahun 2009 karena telah memenuhi kriteria, antara lain kaya dengan simbol-simbol dan filosofi kehidupan rakyat Indonesia serta memberi kontribusi bagi terpeliharanya warisan budaya tak benda pada saat ini dan di masa mendatang.

Faktor pendorong dalam pemilihan batik sebagai warisan budaya tak benda oleh UNESCO dengan menilai jumlah IKM batik Indonesia pada tahun 2008 terdapat sekitar 48.000 dengan penyerapan tenaga kerja sekitar 800.100 orang, dan nilai produksi sekitar Rp2,9 triliun serta memberi kontribusi ekspor mencapai 138 juta dollar AS/tahun (Disperindag, 2007). Perkembangannya saat ini dari data tahun 2019 industri batik yang didominasi oleh industri kecil dan menengah (IKM) ini tersebar di 101 sentra di Indonesia, dengan jumlah sebanyak 47 ribu unit usaha dan telah menyerap tenaga kerja lebih dari 200 ribu orang (Kemenperin, 2019).

Kota Pekalongan sebagai salah satu kota di Indonesia yang menjadi penghasil batik. Batik menjadi produk unggulan utama di Kota Pekalongan, berdasarkan Keputusan Walikota Nomor 530/216 tahun 2002 yang dikeluarkan pada tanggal 1 Mei 2002. Masyarakat di Kota Pekalongan yang sebagian besar penduduknya memiliki mata pencaharian di sektor industri, baik industri batik, konveksi, tenun ATBM dan ATM, serta industri lainnya yang menyebar di seluruh kecamatan di Kota Pekalongan (Sudantoko, 2010).
Perkembangan batik di Kota Pekalongan ini pun tidak hanya terlihat dari sektor industrinya saja, namun juga terlihat dari sektor pariwisata. Penetapan Kota Pekalongan sebagai salah satu kota kreatif di dunia karena industri kreatif di kota ini telah mampu mempromosikan Kota Pekalongan dengan eksistensinya melalui kerajinan batik dan kampung batik di wilayahnya. Kondisi tersebut menjelaskan Kota Pekalongan telah dapat menyatukan sektor industri dengan kegiatan dari sektor pariwisata melalui pariwisata kreatif tersebut (Damayanti \& Latifah, 2015). Perkembangan industri batik juga tidak lepas dari Pemberlakuan Masyarakat Ekonomi Asean menuntut adanya daya saing yang tinggi termasuk pada industri batik. Industri batik di saat ini merupakan bagian dari era digital culture menghasilkan berbagai aplikasi, misalnya media sosial, yang dapat diakses semua kalangan dari seluruh dunia (Darmansa, 2019). Salah satu strategi dalam memasuki era industri 4.0 dalam industri batik adalah pendayagunaan teknologi (Pramono et al., 2018).

\section{METODE PENELITIAN}

Penelitian ini mengidentifikasi bagaimana pembelajaran sosial di dalam usaha industri batik, melalui pendekatan klaster usaha batik di Kota Pekalongan. Pertama melakukan identifikasi rantai usaha produksi batik dan bagaimana pemanfaatan TIK. Identifikasi selanjutnya adalah bagaimana pelaku usaha dihadapkan dengan tantangan pembelajaran sosial dengan regenerasi usaha dan pemanfaatan teknologi dalam pengembangan batik. Hasil dari kajian ini adalah bagaimana peran pemangku kepentingan dalam pengembangan pelaku usaha batik di Kota Pekalongan, dan proses pembelajaran sosial dengan pemanfaatan tekonologi di usaha batik.

Pengumpulan data dilakukan menggunakan metode kualitatif melalui wawancara mendalam kepada pelaku usaha dalam mata rantai industri batik di Kota Pekalongan yang dipilih secara purposive. Data primer penunjang penelitian dilakukan dengan wawancara dan FGD dengan pemerintah daerah terkait dengan proses pembelajaran social, 
ekonomi kreatif, dan preservasi budaya batik. Data primer juga diambil dari dua klaster batik di Kota Pekalongan seperti Klaster Batik Pesindon dan Klaster Batik Kauman. Sedangkan untuk data sekunder perkembangan usaha batik diambil dari tahun 2016 hingga 2020 baik dari kajian yang telah dilakukan sebelumnya dan data statistik.

\section{HASIL DAN PEMBAHASAN \\ 3.1 Perkembangan Industri Pekalongan}

Batik

Kota Pekalongan sebagai salah satu pusat produksi batik di Indonesia tidak terlepas dari sejarah bahwa sejak puluhan dan ratusan tahun lampau hingga sekarang, sebagian besar proses produksi batik Pekalongan dikerjakan di rumahrumah. Kondisi ini menjadikan produk batik Pekalongan menyatu erat dengan kehidupan masyarakat Pekalongan. Batik telah menjadi sumber penghidupan masyarakat Pekalongan dan terbukti tetap dapat eksis dan tidak menyerah pada perkembangan jaman, sekaligus menunjukkan keuletan dan keluwesan masyarakatnya untuk mengadopsi pemikiranpemikiran baru sesuai dengan permintaan pasar.

Berdasakan sejarah, batik di Pekalongan diperkirakan sekitar abad ke-17. Dirhamsyah, (2018), dalam bukunya Pekalongan Yang (tak) Terlupakan menyebutkan Ahmad Ilyas, Peneliti Batik telah menemukan catatan VOC pada tahun 1740 tentang pengiriman kain senilai 20.000 Real Spain (mata uang VOC saat itu). Bahkan menurut data yang tercatat Disperindag Pekalongan, ada motif yang dibuat pada tahun 1802, berupa motif kelopak kecil berupa bahan pakaian. Namun perkembangan yang signifikan diperkirakan terjadi setelah perang besar pada tahun 1825-1830 di Kerajaan Mataram yang sering disebut dengan Perang Diponegoro atau Perang Jawa. Batik dari daerah ini sangat berkembang dan variatif, seperti corak berbagai corak khas India, Persia, Turki, China dan Belanda terlihat mencolok di wajah batik Pekalongan, bahkan menjelang tahun 1940 di Pekalongan, muncul batik dengan corak Jepang, yang disebut batik tulis. Batik Jawa Hokokai (Phelps \& Wijaya, 2016).

Industri Batik hampir runtuh di Era Jepang. Akibat penjajahan Jepang, kondisi ekonomi tidak stabil, banyak orang bahkan tidak bisa makan dengan baik dan industri batik tidak bekerja untuk mendukung kondisi ekonomi. Pada awal tahun 1950, pemerintah pusat memberikan konsesi khusus untuk mendukung harga mori (kain khusus untuk membatik) sehingga produsen dapat memproduksi lebih banyak batik. Era keemasan Batik Pekalongan dimulai pada 1950-an 1970-an ketika industri tekstil dari GKBI ditempatkan di Pekalongan dan mereka menjadi pemasok tekstil untuk semua tempat di Indonesia (Pramono et al., 2018). Hingga pada saat ini batik menjadi warisan budaya UNESCO dan batik menjadi ikon budaya Indonesia.

Sejalan dengan hal tersebut batik Pekalongan turut terkenal di nasional dan internasional. Tantangan pengembangan batik di Kota Pekalongan hasil dari identifikasi awal adalah kondisi lingkungan yang semakin menurun dan mengancam pelaku usaha batik, kedua adalah daya saing wilayah di mana banyak daerah yang mulai memproduksi batik dan terakhir adalah regernerasi pelaku usaha. Hal ini yang harus diselesaikan oleh pemangku kepentingan.

\subsection{Potensi Batik Kota Pekalongan}

Potensi produk batik terhadap perekonomian wilayah Pekalongan dapat ditinjau dari 2 sektor, yaitu: sektor industri pengolahan pada sub-sektor industri tekstil dan pakaian jadi serta sektor perdagangan besar dan eceran pada sub-sektor perdagangan besar dan eceran (PEL Batik Pekalongan, 2017). Kontribusi masing-masing sektor tersebut terhadap perekonomian Kota Pekalongan dapat dilihat dalam Pendapatan Domestik Regional Bruto (PDRB) Atas Dasar Harga Berlaku Tahun 2016-2020. Adapun kontribusi untuk masing-masing sektor yaitu sebesar $21,16 \%$ untuk sektor perdagangan besar dan eceran serta $21,40 \%$ untuk sektor industri pengolahan (BPS, 2021). 


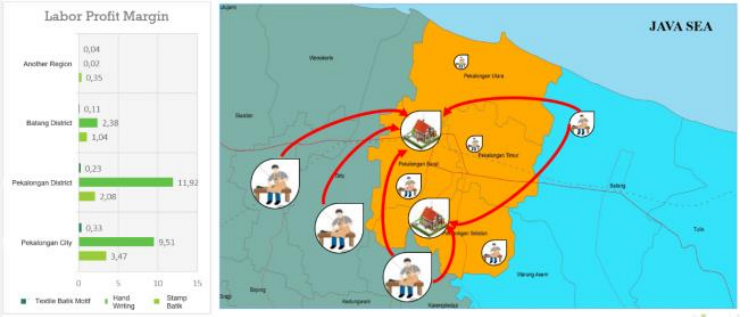

Gambar 1 Peta Produksi Batik

Perkembangan batik tidak hanya dimiliki oleh Kota Pekalongan saja, dalam keruangan terbagi menjadi perkembangan batik di perkotaan (Kota Pekalongan) dan pedesaan (Kabupaten Pekalongan) seperti Gambar 1. Industri batik di Kota Pekalongan memberikan sumbangan yang besar dalam kemajuan perekonomian dengan mayoritas dari industri rumah tangga. Kota Pekalongan memiliki kurang lebih 634 industri batik dengan daya serap sebanyak 9.944 tenaga kerja (Astuti, 2016). Jumlah yang sama juga tumbuh di Kabupaten Pekalongan sebanyak 645 IKM (industri) di Kabupaten Pekalongan yang terdaftar (Disperindag Kab. Pekalongan 2019).

Tabel 1 Sebaran Pelaku Usaha Batik Kota Pekalongan

\begin{tabular}{cclll}
\hline \multirow{2}{*}{ No } & \multirow{2}{*}{ Kecamatan } & Klaster Batik & $\begin{array}{l}\text { Pelaku } \\
\text { Usaha }\end{array}$ & Pekerja \\
\hline 1. & Pekalongan & Medono & 31 & 142 \\
& Barat & Sapuro & 22 & 44 \\
& & Bendan & 24 & 221 \\
& & Pasir & 107 & 1468 \\
& & Pringlangu & 46 & 464 \\
2. & Pekalongan & Tirto & 60 & 870 \\
& Kauman & 30 & 434 \\
3. & Pekalongan & Banyurip & 46 & 505 \\
& Selatan & Ageng & & \\
& & Banyurip Alit & 88 & 285 \\
& & Buaran & 59 & 336 \\
4. & Pekalongan & Jenggot & 118 & 788 \\
& Utara & Krapyak Kidul & 22 & 348 \\
\hline
\end{tabular}

Sumber: PEL Batik Kota Pekalongan 2017

\subsection{Tantangan Pengembangan Industri Batik}

Kawasan Pekalongan sebagai pusat budaya batik tidak lepas dari jumlah pelaku usaha dan pekerja batik yang terlibat dalam proses produksi, tercatat terdapat 5 (lima) pelaku usaha yang teridentifikasi dalam rantai nilai batik pada tahun 2017. Sebaran keuntungan keruangan dari pendapatan tenaga kerja di usaha batik terpusat di Kota Pekalongan dan
Kabupaten Pekalongan terlihat di gambar peta sebaran pekerja batik (Gambar 2). Rata-rata keuntungan paling besar didapat oleh pengrajin atau pemilik usaha sedangkan margin paling kecil adalah buruh batik. Selisih pendapatan yang besar antara pemilik usaha dan pekerja/buruh batik menjadikan perbedaan tingkat kesejahteraan (Gambar 3).

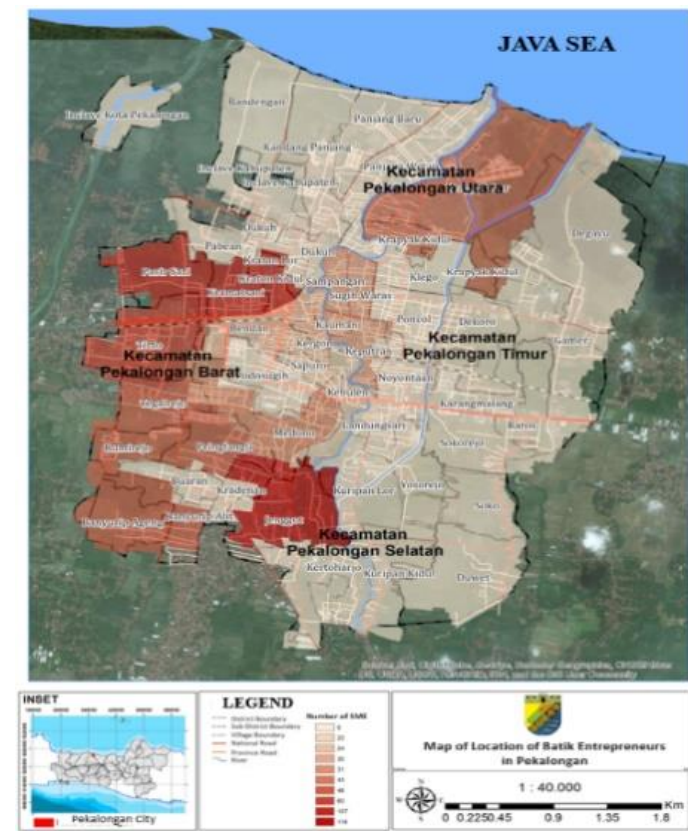

Gambar 2 Peta Tenaga Kerja Batik Kota Pekalongan

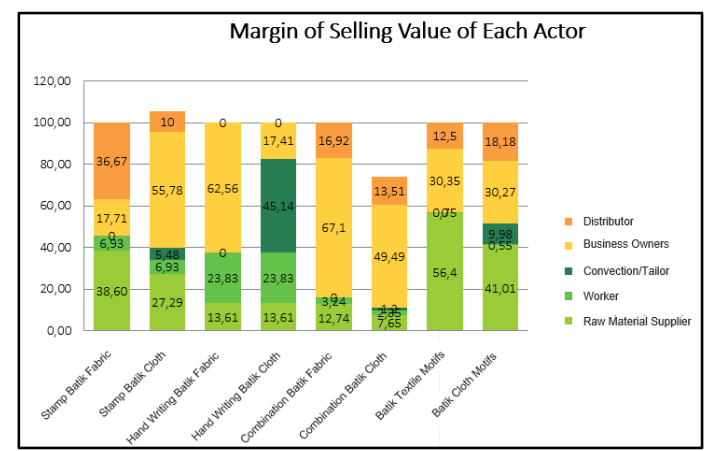

Gambar 3 Margin Keuntungan Batik Kota Pekalongan

Data penunjang lain mengindikasikan jumlah pekerja di sektor industri pengolahan (di dalamnya terdapat industri batik) di wilayah Kota dan Kabupaten Pekalongan menempati nilai yang tinggi diikuti oleh sektor perdagangan. Penyerapan yang tinggi di sektor industri pengolahan tidak serta merta diikuti oleh indek pembangunan manusianya. Dari data BPS 2017 teridentifikasi ada kesenjangan pembangunan antara kota dan kabupaten. 


\subsection{Proses Pembelajaran Sosial}

Hasil identifikasi pertalian nilai dari pelaku usaha di Kota dan Kabupaten Pekalongan menggambarkan proses kegiatan batik di kawasan ini tidak berjalan dengan selaras. Ketimpangan pemilik usaha dan pekerja menjadikan regenerasi pelaku batik menurun. Analisis selajutnya dilakukan dengan pembelajaran sosial untuk mengetahui proses transfer informasi dan pengetahuan dalam usaha batik berjalan dengan baik atau tidak

Peran Klaster Batik Kauman dalam Membantu Kegiatan

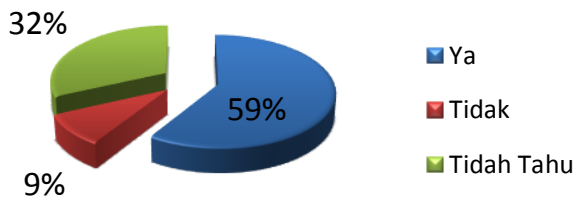

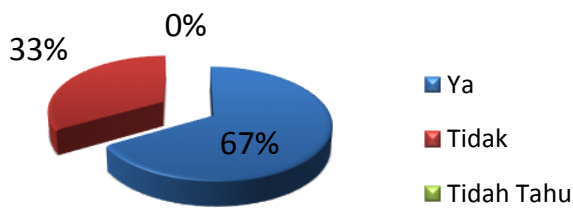

Gambar 4 Peran Pembelajaran Sosial dalam Kegiatan Klaster Usaha

Analisis pembelajaran sosial dalam pengembangan batik ini dilihat dari modal sosial yang dimiliki pelaku usaha maupun pemerintah kota. Di mana sebenarnya pemerintah memberikan pelayanan publik agar masyarakat mampu memberdayakan potensi sumber daya yang dimilikinya. Pemerintah dalam memfasilitasi pemberdayaan ini melalui forum yang dibentuk dengan tujuan mempermudah memasukan unsur-unsur pembelajaran agar masyarakat mampu berdaya dan masyarakat sendiri sebagai penggerak dari pemberdayaan ini.

Pelaku usaha yang diidentifikasi dari klaster usaha batik Pesindon dan Kauman sebagian besar mendapatkan bantuan dari klaster. Gambar 4 menjelaskan sebagian besar aggota klaster mendapatkan pembelajaran dalam menjalankan usaha. Secara lebih rinci dibahas dalam beberapa variabel antara lain informasi, pengetahuan dan keterampilan, modal, posisi tawar dan kebersamaan.

Pembelajaran sosial dilihat dari proses pemberdayaan masyarakat dan hasil dari proses peberdayaan yaitu keberdayaan masyarakat. Untuk melihat seberapa berhasilnya keberdayaan yang dilakukan oleh pemberdaya perlu dilihat penggunaan teknologi (Gertler, Meric S; Wolfe, 2002),

Informasi. Informasi yang baik dan benar dapat dijadikan alat pemberdayaan dalam menentukan keputusan apa yang akan diambil dalam peningkatan kualitas hidup. Peran ini dilakukan selama ini oleh lembaga baik yang di bawah pemerintah seperti FEDEP (Forum for Economic Development and Employment Promotio) Kota Pekalongan dengan klaster binaan seperti Klaster Batik Pesindon, Klaster Batik Kauman, yang menjadi lokasi studi. Informasi disampaikan oleh pengurus klaster seperti, promosi pameran, edukasi penggunaan bahan, teknik dan pengembangan usaha seperti pariwisata (edutourism) yang diberikan oleh pemerintah maupun swasta.

Kemudahaan informasi di era digital juga dimanfaatkan pelaku usaha tidak hanya sebagai media pemasaran tetapi juga dalam penyampaian informasi lainnya. Informasi pelatihan dan proses pelatihan juga memanfaatkan TIK terutama di masa pandemi Covid-19 seperti webinar yang dilakukan akademisi, swasata maupun pemerintah Kota Pekalongan.

Pengetahuan dan Ketrampilan. Pelatihan dalam pembangunan fisik di mana individu memiliki keterampilan teknis dapat dijadikan potensi yang dimiliki dalam pengembangan klaster batik. Sistematika pembelajaran dilakukan dengan melatih pengurus klaster usaha batik untuk disebarkan kepada pelaku usaha lainnya. Forum-forum ini dinilai efektif dalam meningkatkan keterampilan pelaku usaha atau anggota kelompok. 
Pengetahuan dan keterampilan juga mulai merambah ke penggunaan TIK seperti media design untuk inovasi batik, pemasaran melalui e-commerce telah dilakukan. Pada tahap ini generasi muda lebih memahami keterbaruan teknologi. Hal ini yang menjadi peluang dalam menumbuhkan minat usaha batik di generasi penerus.

Modal. Modal merupakan variabel terpenting guna mendirikan usaha secara bertahap. Modal dibagi menjadi dua yaitu modal usaha dan modal sosial (Thobias et al., 2013). Modal usaha saat ini selalu menjadi tantangan dalam dunia usaha batik apalagi dengan kondisi pandemi Covid-19. Berkaitan dengan kondisi permasalahan terkait permodalan dalam menjalankan usaha batik, Pemerintah Kota Pekalongan melalui Dinas Perdagangan, Koperasi dan UKM Kota Pekalongan mempertemukan pedagang, pelaku UMKM, lembaga keuangan dalam suatu forum yaitu micro finance expo, di mana acara ini memberikan pengetahuan terhadap para pelaku usaha batik untuk dapat mengakses pinjaman modal baik itu ke bank maupun lembaga keuangan bukan bank.

Di sisi lain modal sosial pelaku usaha batik sangatlah kuat di mana sistem budaya dan kekerabatan masih terjaga. Kondisi ini menguntungkan dalam proses pembelajaran batik, karena dengan kondisi ini memudahkan menyampaikan informasi. Tantangan dalam tahap ini adalah menumbuhkan minat bagi generasi muda untuk melakukan usaha.

Posisi Tawar. Organisasi dan lembaga kemasyarakatan menggerakkan dan menyalurkan aspirasi masyarakat. Pengelolaan Kampung Batik Pesindon dikelola oleh sekretariat dengan struktur organisasi dimulai dengan ketua hingga anggota. Pengelolaan organisasi kampung batik juga mendapatkan bantuan dari pemerintah melalui FEDEP selaku pendamping klaster batik di Kota Pekalongan dan dari akademisi baik dari PUSMANU dan Universitas Pekalongan.

Perkembangan kampung batik dewasa ini mengalami kendala terutama dalam reorganisasi kepengurusan, banyak generasi muda yang tidak mau melanjutkan kepengurusan. Hal ini sejalan dengan kurangnya generasi muda yang bergelut di bidang batik, meskipun terdapat beberapa sekolah menengah kejuruan batik di kota Pekalongan. Kendala regenarasi pembatik ini diakibatkan ketertarikan generasi muda yang lebih memilih kerja di industri garmen dengan pendapatan yang lebih besar.

Kebersamaan. Kerjasama kolektif diperlukan untuk menciptakan efesiensi kolektif. Sebagai contoh di tabel 2.

Tabel 2 Peran Pemangku Kepentingan

\begin{tabular}{|c|c|c|}
\hline $\begin{array}{l}\text { Kelompok } \\
\text { Pelaku }\end{array}$ & $\begin{array}{c}\text { Pelaku yang } \\
\text { Terlibat }\end{array}$ & Peran \\
\hline $\begin{array}{l}\text { Pengrajin } \\
\text { Industri } \\
\text { Batik }\end{array}$ & 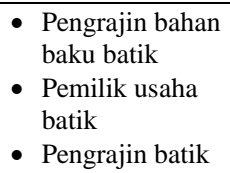 & $\begin{array}{l}\text { - Penyedia bahan baku } \\
\text { - Produsen batik } \\
\text { - Pemasaran batik ke } \\
\text { konsumen }\end{array}$ \\
\hline Pemerintah & $\begin{array}{l}\text { - Disperindagkop } \\
\text { \& UMKM } \\
\text { - Disperindag } \\
\text { Provinsi } \\
\text { - Bappeda } \\
\text { - Kemenperin } \\
\text { - BPPT } \\
\text { - Kemenristek }\end{array}$ & $\begin{array}{l}\text { - Fasilitator dalam } \\
\text { mempertemukan } \\
\text { pelaku klaster, } \\
\text { penyedia infrastruktur, } \\
\text { perumus kebijakan dan } \\
\text { regulasi terkait klaster } \\
\text { - Penyedia informasi, } \\
\text { dana, dan pasar bagi } \\
\text { UMKM Batik } \\
\text { - Penyedia tenaga kerja } \\
\text { yang terampil }\end{array}$ \\
\hline Swasta & $\begin{array}{l}\text { - PT. Telkom } \\
\text { - PT. Perhutani } \\
\text { - Pertamina }\end{array}$ & $\begin{array}{l}\text { Pemberian pembinaan } \\
\text { dan pendampingan } \\
\text { klaster batik }\end{array}$ \\
\hline $\begin{array}{l}\text { Lembaga } \\
\text { pembiayaan } \\
\text { bank dan } \\
\text { non bank }\end{array}$ & $\begin{array}{l}\text { - Kopena } \\
\text { - Kospin Jasa } \\
\text { - BRI } \\
\text { - BNI } \\
\text { - PT. Telkom }\end{array}$ & $\begin{array}{l}\text { Fasilitasi pendanaan } \\
\text { dan pengembangan } \\
\text { pasar } \\
\text { - Sumber dana berupa } \\
\text { investasi dan } \\
\text { peminjaman modal }\end{array}$ \\
\hline Akademisi & $\begin{array}{l}\text { - Universitas } \\
\text { Pekalongan } \\
\text { - Politeknik } \\
\text { Pekalongan } \\
\text { - Pusmanu } \\
\text { - SMK Batik }\end{array}$ & $\begin{array}{l}\text { - Melakukan riset untuk } \\
\text { pengembangan klaster } \\
\text { batik } \\
\text { - Penyedia tenaga kerja } \\
\text { yang berkualitas bagi } \\
\text { pengembangan klaster } \\
\text { batik yang ada }\end{array}$ \\
\hline Asosiasi & $\begin{array}{l}\text { - } \text { BDS } \\
\text { - Fedep Kota } \\
\text { - Asosiasi Pecinta } \\
\text { Batik } \\
\text { - Paguyuban } \\
\text { Pecinta Batik }\end{array}$ & $\begin{array}{l}\text { - Lembaga pendamping } \\
\text { yang mengawasi peran } \\
\text { masing-masing pihak } \\
\text { yang terlibat di dalam } \\
\text { klaster } \\
\text { - Penyedia jasa } \\
\text { informasi terkait } \\
\text { pengembangan ide dan } \\
\text { strategi } \\
\text { - Mempertemukan } \\
\text { pelaku usaha untuk } \\
\text { pengembangan pasar }\end{array}$ \\
\hline
\end{tabular}




\section{SIMPULAN DAN SARAN \\ 4.1. Simpulan}

Hasil pembelajaran sosial di dalam usaha batik di Kota Pekalongan telah berusaha untuk menunjukkan bagaimana seperangkat praktik pengembangan produk yang diterapkan pelaku usaha dan pemangku kebijakan di dalam industri batik di Kota Pekalongan. Dari segi perkembangan usaha diketahui produksi batik di Pekalongan tidak hanya mewarisi dan menjalankan budaya tetapi juga meningkatkan kapasitas bisnis yang mampu menembus pasar internasional. Secara keruangan Kota Pekalongan dan wilayah sekitarnya memiliki peran tersendiri, seperti Kota Pekalongan sebagai pusat kegiatan dan pemasaran sedangkan wilayah di sekitarnya merupakan supporting system sebagai penyedia tenaga kerja dan ruang produksi.

Hasil kedua adalah terkait dengan identifikasi pembelajaran sosial yang dilakukan oleh pelaku usaha batik dan stakeholder terkait dalam melestarikan batik di Kota Pekalongan. Pembelajaran sosial di produk unggulan batik dilakukan melalui kelompok seperti klaster usaha batik. Hasil yang diperoleh bahwa pembelajaran sosial telah dilakukan dengan baik sesuai dengan komponen pembelajaran sosial tetapi belum melihatkan hasil terutama dalam regenerasi. Pembelajaran sosial yang belum optimal terkait informasi, pengetahuan dan keterampilan yang telah dibagikan kepada generasi selanjutnya. Tantangan di pembelajaran sosial ini adalah menyasar pekerja lepas/buruh batik untuk meningkatkan kesejahteraannya dengan kualitas keterampilan yang dimiliki.

Keterkaitan perkembangan produk unggulan batik dan proses pembelajaran sosial terdapat beberapa dukungan tetapi masih terdapat sebagian besar pelaku usaha di Kota Pekalongan masih menjalankan usaha sebagai bisnis. Proses pembelajaran sosial dalam pengembangan usaha hanya terasa kemanfaatannya di klaster usaha/kelompok usaha terutama yang mendapat dukungan stakeholder pembangunan.

\subsection{Saran}

Kemanfaatan hasil penelitian ini bagi pemerintah kota bahwa produk unggulan batik ini tidak muncul dari beberapa budaya bisnis statis yang diwarisi, tetapi sebaliknya sangat dipengaruhi oleh seperangkat institusi/ kelembagaan seperti pemerintah maupun akademisi dalam memberikan pembelajaran untuk meningkatkan kapasitas pelaku usaha. Program pembelajaran sosial melalui pemberdayaan pelaku usaha dengan diversifikasi produk yang tidak hanya batik tetapi seperti wisata edukasi menjadi strategi pengembangan ke depannya. Dalam program ini akan terjadi proses pembelajaran sosial dari pelaku usaha kepada masyarakat. Selain itu pengembangan digital baik pemasaran maupun pendidikan berupa informasi dan pelatihan di pandemi Covid-19 menjadi hal yang penting untuk segera dilakukan.

Rekomendasi hasil dari penelitian ini diharapkan mampu dikembangkan penelitanpenelitan terkait penguatan modal sosial seperti mengidentifikasi kewirausahaan sosial dalam meningkatkan kualitas lingkungan dan produk batik di Kota Pekalongan.

\section{REFERENSI}

Astuti, D. (2016). Hubungan dan Aliran Informasi Antar Pelaku pada Klaster Batik Kota Pekalongan. 4(April), 29-44. https://doi.org/10.14710/jwl.4.1.29-44

Damayanti, M., \& Latifah, L. (2015). Strategi Kota Pekalongan Dalam Pengembangan Wisata Kreatif Berbasis Industri Batik. Jurnal Pengembangan Kota, 3(2), 100. https://doi.org/10.14710/jpk.3.2.100-111

Darmansa, J. N. (2019). Identifikasi minat generasi $\mathrm{z}$ terhadap ragam hias batik belanda. Sosioteknologi ITB, 232-241.

Dirhamsyah, M. (2018). Pekalongan yang (tak) terlupakan: sebuah katalog warisan budaya. Dinas Kearsipan dan Perpustakaan Kota Pekalongan.

Gertler, Meric S; Wolfe, D. A. (2002). Innovation and Social Learning: Institutional Adaptation in an Era of Technological Change. PALGRAVE MACMILLAN.

Handayani, R. A. (2016). Pengaruh Minat Remaja Dalam Pemakaian Batik 
Terhadap Pelestarian Batik Kudus. 1, 157.

Jannah, S., Indrawati, I., Rahayu, H. D., Marwan, S., Najmuddin, M. K., Mufaiz, M. T., Dewantoro, A., Mega, K. I., Almukri, M. S., Suhermanto, A. Y., Hidayah, D. Z. M., \& Putri, M. R. (2020). Meningkatkan Eksistensi dan Pelestarian Batik di Era Modern. Jurnal Pembelajaran Pemberdayaan Masyarakat $\begin{array}{lll}(J P 2 M), & 1(2), & 139\end{array}$ https://doi.org/10.33474/jp2m.v1i2.6536

Kusuma, M. (2015). PERAN SAUDAGAR DALAM PELESTARIAN BATIK SOLO (Studi kasus di kampung Batik Laweyan, Kota Solo). 1-87.

Maulana, M. R., Rusli, C. Y., \& Kurniawan, I. (2016). Pemanfaatan Virtual Reality Untuk Pengembangan Kios Informasi Objek Wisata Di Kota Pekalongan Berbasis Mobile. Jurnal Litbang Kota Pekalongan, 11, 23-41.

Nicholas A. Phelps. (2019). Growth and growth constraints in craft industry clusters: The batik industries of Central Java. September 2019, 1-36.

Nurainun, N. (2008). Analisis Industri Batik Di Indonesia. Fokus Ekonomi, 7(3), 124-135.

Phelps, N. A., \& Wijaya, H. B. (2016). Joint action in action? Local economic development forums and industry cluster development in Central Java, Indonesia. International Development Planning Review, 38(4), 425-448. https://doi.org/10.3828/idpr.2016.24

Pramono, S., Sabana, S., \& Haldani, A. (2018). Transformasi Batik Dan Globalisasi. Jurnal Dimensi Seni Rupa Dan Desain, 15(1), 55. https://doi.org/10.25105/dim.v15i1.4199

Sudantoko, D. (2010). Pemberdayaan Industri Batik Skala Kecil Di Jawa Tengah Program Pasca Sarjana Universitas Diponegoro Semarang 2010.

Sulistyorini, P., Royanti, I. N., \& Yunianto, E. (2017). Pengaruh Adopsi E-commerce terhadap Keberhasilan Usaha.

Tamamudi. (2019). Perilaku Produksi Industri Batik Kota Pekalongan Menurut Etika Produksi Islam. Journal of Chemical Information and Modeling, 53(9), 16891699. https://doi.org/10.1017/CBO97811074153 24.004

Taryadi, Yunianto, E., \& Royani, N. I. (2015). Analisis Tingkat Kesiapan Adopsi EMarketplace Umkm Batik Di Kota Pekalongan. Litbang Kota Pekalongan, 8, 19-31.

Thobias, E., Tungka, A. K., \& Rogahang, J. J. (2013). Pengaruh Modal Sosial Terhadap Perilaku Kewirausahaan (Suatu studi pada pelaku usaha mikro kecil menengah di Kecamatan Kabaruan Kabupaten Kepulauan Talaud). Acta Diurna, April, 1-23.

Wijaya, M. I. H., Ariani, N. M., \& Priambudi, B. N. (2020). Identifikasi Peran Kewilayahan Dalam Pengembangan Produk Unggulan Batik Di Kawasan Pekalongan. 4(2), 112-122. https://jurnal.pekalongankab.go.id/index.p hp/jurnalkabpekalongan/article/view/99/5 0

https://kemenperin.go.id/artikel/21985/Kemenp erin-Dorong-Pelaku-Industri-BatikTerapkan-Praktik-Ramah-Lingkungan 